\title{
Developing Strategies for Instruction and Assessment of Infographics for First- Year Technology Students
}

\section{Asefeh Kardgar, Purdue Polytechnic Institute}

Asefeh Kardgar is currently a master student in Computer Graphics Technology at Purdue polytechnic Institute, West Lafayette.

\section{Prof. Nathan Mentzer, Purdue University, West Lafayette (College of Engineering)}

Nathan Mentzer is an assistant professor in the College of Technology with a joint appointment in the College of Education at Purdue University. Hired as a part of the strategic P12 STEM initiative, he prepares Engineering/Technology candidates for teacher licensure. Dr. Mentzer's educational efforts in pedagogical content knowledge are guided by a research theme centered in student learning of engineering design thinking on the secondary level. Nathan was a former middle and high school technology educator in Montana prior to pursuing a doctoral degree. He was a National Center for Engineering and Technology Education (NCETE) Fellow at Utah State University while pursuing a Ph.D. in Curriculum and Instruction. After graduation he completed a one year appointment with the Center as a postdoctoral researcher.

\section{Dr. Dawn Laux, Purdue University}

Dawn Laux is a Clinical Associate Professor in the Department of Computer and Information Technology (CIT) at Purdue University. She has been with the University since 2007 and is responsible for teaching database fundamentals courses and introductory technology courses. Laux has 10 years of industrial experience in the information technology field, and her research area of interest includes technology readiness, the social impacts of technology, and increasing interest in the field of computing.

\section{Amelia Chesley, Purdue University}

Amelia Chesley is currently a PhD candidate in Rhetoric and Composition at Purdue University. She is interested in intellectual property, remix culture, transdisciplinarity, and online communities. Her dissertation research investigates the public curation and digitization work being performed by volunteers for the audiobook archive LibriVox.

\section{Dr. David M. Whittinghill, Purdue University, West Lafayette (College of Engineering)}

Dr. David Whittinghill is an Assistant Professor of Computer Graphics Technology and Computer and Information Technology. Dr. Whittinghill' s research focuses on gaming, simulation and computer programming education and how these technologies can more effectively address outstanding issues in health, education, and society. Dr. Whittinghill leads projects in virtual reality, pediatric physical therapy, sustainable energy simulation, Chinese language learning, and games as a tool for improving educational outcomes. Dr. Whittinghill is the director of the Games Innovation Laboratory (www.gamesinnovation.org). 


\begin{abstract}
This evidence-based practice presentation discusses the teaching of an infographics assignment to first-year technology majors at a large research institution. Infographics can be powerful and successful methods of presenting large, complex data sets to general audiences, and the growing importance of visual communication has been documented. With a goal of improving our instruction and assessment of visual communication skills, we compare infographics designed and produced by freshman students during Fall 2015 with those produced by Fall 2016 freshman students in the same introductory design course, and investigate whether freshman students' abilities to communicate graphically change or improve significantly with more in-depth instruction and guidance. Collecting, comparing, and analyzing student-produced infographics in this pilot study will help us begin to measure the effects and value of our course development in this important area of design communication.

\section{Introduction}

Infographic is a visual picture to shows information, data and knowledge. The goal of infographic is to present information quickly and clearly. The importance of visual communication has been well documented. Statistician and Information designer Edward Tufte (1997) has written extensively about how indispensable images can be in representations of cause and effect, processes, motion, thought, and relationships. Infographics in particular are lauded as powerful and successful (when done well) methods of presenting complex and large data sets to general audiences (Tufte, 1997; Smiciklas, 2012; Lankow, Ritchie, \& Crooks, 2012). An ongoing proliferation of multimedia communication also means that visual literacy skills continue to grow more and more valuable for students and college graduates, and teaching these skills is becoming important to multiple academic disciplines. Teaching visual literacy will ideally help students to interpret the mass of visual media they encounter as young people, and in turn help them to apply and extend those critical skills within their future careers. Kibar and Akkoyunlu (2014) have discussed the use of infographics as a tool for teaching visual literacy skills. They found that students become more powerful in information organization skills. Those skills are related to colors and fonts in which the students need more work to do. Similarly, Mendenhall \& Summers (2015) outlined ways infographics assignments are helpful for teaching design thinking, synthesis of information, and research presentation. They mentioned that infographics could be useful for different kinds of research project and design. These infographics can help student to develop awareness of their project that they want to do it. Knowing the value of visual communication skills, administrators and instructors of an introductory technology course incorporate visual presentations and an infographic assignment into the final design project of the course. In this article, we discuss how this infographics assignment has been taught in a required course for first-year technology majors at a large research institution. As part of the final group project in this design course, students developed infographics to visualize and promote the solutions they design in response to one of the National Academy of Engineering global grand challenges (NAE, 2016). Each group then incorporated their infographics into a formal presentation about their solution.

With a long-term goal of improving our instruction and assessment of visual communication skills, we have compared infographics designed and produced by freshman students during Fall 2015 with those produced during Fall 2016 by freshman students in the same introductory design course. This comparison allows us to investigate whether freshman students' abilities to communicate graphically change or improve significantly with more in-depth instruction and guidance. This paper will provide audience members with an overview of this data and analysis,
\end{abstract}


an example of the detailed rubric, 12 research-vetted tips for students on generating effective infographics, and the accompanying take-home quiz. Our collection, comparison, and analysis of student-produced infographics over multiple semesters is beginning to help us measure the effects and value of our course development in this important area of design communication.

\section{Previous Research on Infographics and Pedagogy}

An infographic usually uses visual graphic to represent the information. In this paper we use "infographic" to mean a graphic visual representation of information, data or knowledge intended to present complex information quickly and clearly (Learning Commons Library, 2014). Infographics improve cognition by using pictures and graphs to improve audiences' visual system power to get the patterns and message faster. The combination of textual and graphic visual components, including charts, diagrams, symbols, and picture used to represent information or data.

"Visualization allows people to offload cognition to the perceptual system, using carefully designed images as a form of external memory. The human visual system is a very highbandwidth channel to the brain, with a significant amount of processing occurring in parallel and at the pre-conscious level." (Munzer 2009).

"The science of visualization shows that we process information using our eyes presents compelling rationale for considering the use of infographics in your business communication mix." (Smiciklas 2012).

Lankow, Ritchie, \& Crooks, 2012: "The visualization of information is enabling us to gain insight and understanding quickly and efficiently, utilizing the incredible processing power of the human visual system. Accessing and harnessing this power is not only valuable, but necessary, as we navigate the vast amounts of data presented to us daily." (Page 10) Infographics should attract the attention and be easy and fast to understand. (Smiciklas 2012) Storytelling and flow are the important features of infographics. "The infographics should also use credible, useful data or information, contextualized well for the audiences it seeks to address." (Krauss 2012).

Infographics applied in education, especially the design education, become more challenging to design teaching. Analyzing the relationship between infographics and design education is very important. Design education make ready designers for business and society. Dyjur \& Li

discussed that for developing 21 st century skills, teachers need to teach their students' skills like "effective communication and critical thinking". For improving those 21 st century skills, they develop an infographic for an assignment in an Education Master's level course and then evaluating the effective use of it. Students mentioned that those infographics assignments were effective for their visual literacy skills and helped them to increase their critical analysis and visual information abilities. Dyjur \& Li (2015)

Toth offers two approaches to increase awareness and exposure of infographics for students. The first focuses were on assignment analysis using infographics; the second focuses were on a production assignment. (Toth, 2013) Instructors often have teaching infographics and offer "essential steps" for effectively incorporating infographics to improve design education overall. (Ru \& Ming, 2014) Infographics can be created by graph paper, pencils, markers, and rulers, or much faster and more easily with computer software. Some websites provide easy tools and templates as starting places.

\section{The Design Thinking Course}


The introductory design-thinking course is required for all technology majors at this research university. The course pushes students to engage with the design process (ideation, research/benchmarking, prototyping, feedback, repeat, etc.) and expects them to practice critical thinking, creativity, innovation, logic, and problem solving. The grand challenges assignment asks that students collaboratively grapple with a global issue, work to understand the complexities of the problem, zoom in on a local version/manifestation of the problem, conduct research, and then brainstorm, design, prototype, and test a solution to that problem. Each group of 4-5 students then incorporated their infographics into a persuasive presentation about their solution and why it should be funded. Part of the practical context for these student projects involves a pitch to potential funding agencies. Student teams are expected to describe their project, highlight their design process, and persuade potential investors to support the solution's development and/or production. One piece of this assignment involves designing an infographic, for either this audience or another relevant, interested audience, explaining some facet of their design solution in a coherent, easy-to-understand set of visuals.

Students during the fall 2015 semester were provided with a selection of web-based infographic templates and 50 minutes of class time in which they brainstormed and developed their infographics. They worked in groups of 4-6 students each, with supervision and assistance from their instructor and one undergraduate TA. Preliminary analysis of student submitted infographics from fall 2015 showed that students interpreted the assignment and the purpose of their infographics in a wide variety of ways. Most students relied heavily on limited, pre-made templates for generating their infographics, worked with only minimal guidance and a very simple rubric provided by instructors (see Appendix B), and may have seen this project as a very minor segment of their overall final project. Student groups did create visually interesting products, but the infographics' content, sequencing, and overall storytelling was more erratic and not always effective.

Our hypothesis is that fall 2016 infographics will have higher scores on this new rubric because of the added teaching materials. These added measures will ideally help students create better/more effective group visualizations for their projects. We also hope that when students learn to use the proposed rubric as a learning tool and evaluation measure, students' abilities to creatively conceptualize and produce relevant infographics, without copying existing templates, are improved significantly.

According to existing rubrics and point out a gap in what's out there, signpost about how we go on to fill that gap by expanding/improving the existing rubric. Extending it with extra assignments, readings, and quiz to really reinforce the principles of effective infographics.

\section{Pedagogical Improvements for Teaching Infographics}

In this section, we detail the improvements made to the infographics portion of this final design project. Using insights from existing literature, in combination with what we learned from analyzing student-produced infographics from 2015, we developed a more robust rubric and additional scaffolding assignments to be used the following year. After analyzing students' infographics in 2015, most graders complained that students usually just rely on template and their works are good visually. However, they were not good enough to show the message and flow. They rarely cited their works and chose a topic for their infographics. Since the previous rubric did not ask them to cover those parts (Appendix B), there was a need for a new pedagogical elements including Rubric (Appendix A), Quiz (Appendix C), Patel (2015), Krauss (2012). These elements were introduced during November of the 2016 fall semester for 12 sections (of 40-45 students each) of the Design Thinking course. 
In addition to a full 50-minute class period in which to develop infographics with their group, students in the Fall 2016 version of the course was given:

- a more detailed rubric to guide their design process

- assigned readings on principles for creating effective infographics

- a concise 12-point tip sheet on creating successful infographics (based on the rubric)

- a take-home quiz covering important infographics design principles

- an individual draft infographics assignment to be completed at home before class

Preparation for this infographics assignment began at week 13 of the fall 2016 semester, at which point students had been working on their final grand challenges projects for 2 weeks.

As they began the final project (week 11), students were given access to this full rubric and other materials via the online course management platform. The work of the final projects spanned 5 weeks, and the infographics portion took up approximately $1 / 2$ week of this time. Before class, students were to have read the assigned article, taken the online quiz, and developed an individual draft infographic. Group discussion and work on a collaborative infographic draft then took place during one 50-minute class period. Additional details about these added activities and resources are included in the following sections.

\section{Infographics Rubric}

The Fall 2015 infographics rubric (see Appendix A) included three basic questions about whether students' infographics told a story, highlighted useful information, and looked professional. A survey of other existing infographics rubrics specifically geared toward evaluating student work shows that for the most part they are similarly brief and simple, covering content and design in broad strokes (Bruff 2012; Kaiser 2012). Kathy Schrock (2012) has published a more extensive rubric and some explanation of important infographic components for students and instructors to recognize. Bruff (2012) and Kaiser (2012) both reference Schrock's work and link to rubric examples they have developed themselves. Bruff (2012) gives a list of requirements and basic yes/no questions for evaluation. Schrock mainly focuses on visualization skills and graphic design in her rubric rather than the flow and storytelling features emphasized by Lankow, Ritchie \& Crooks (2012), Mckee \& Fryer (2003). The Schrock rubric covers 9 categories of criteria, each listed with specific descriptions at 3 levels of completion: "exceeds expectations," "meets expectations," or "needs work."

We have adapted Kathy Shrock's (2012) rubric for information visualization in combination with what we learned from reviewing student-produced infographics from fall 2015. Our additions and refinements to the infographic rubric emphasize the composition's purpose, sense of flow or storytelling, and clear message communicated. This new rubric covers 11 important categories of information design, including crucial considerations of audience, structure and size, topic and coherence, storytelling and flow, research credibility, and formatting (see Appendix A). All 11 criteria are evaluated at three levels, similarly to the criteria in Schrock's rubric. Compared to the pre-existing fall 2015 infographic rubric, this new grading tool is much more detailed and in line with research on visualization principles.

\section{Readings and tips}

Students in the fall 2016 version of the course was assigned new readings related to this assignment:

- "12 Infographic Tips That You Wish You Knew Years Ago" by Neil Patel

- "Infographics: More than Words Can Say" by Jane Krauss

- "Introduction to Infographics: Library Workshop" by the Learning Commons Library 
The Patel (n.d) blogpost was required reading, while the Krauss (2012) and Learning Commons Library slide set (2014) were assigned as optional. All three include several examples and review similar design principles: tell a story, use images/visuals that fit the purpose of your infographic, and so on. The Patel (n.d.) piece covers the importance of simplicity, focus, making good use of space, color, and thinking carefully about size/shape/readability. He stresses the fact that simply creating an infographic is not enough, by itself, to get attention--it needs to be a good one, targeted to a specific audience, designed well, supported by accurate information, and promoted well.

Take-home (online) Quiz

After the readings, a simple quiz is assigned to students. Pairs of example infographics are presented, and students are asked to choose which best demonstrates (or fails to demonstrate) the principles of effective data/information visualization. The quiz presents exaggerated comparisons in order to teach students the important parts of the rubric by which their infographics will be judged. It is an easy assessment, meant to plant these important principles in their heads and prompt them to remember them when making choices about their own designs.

One example quiz question is included here:

10- Which infographics cites the sources?

There would be two options for students. The first one with infographic that is clearly cited in APA format and the other is the infographic that has not citation. Students need to look at both infographic and choose the right one.

All the quiz questions are available in Appendix C.

Individual Infographic Drafts

In addition to a full 50-minute class period in which to develop infographics with their group, all students were asked to create individual infographic drafts at home before coming to class to work with their group members. This activity, along with the quiz, was meant to help students begin practicing the principles of infographic outside of class. The activity also exposes students to various online tools and templates for creating simple infographics--primarily Easelly (Available: https://www.easel.ly), and potentially others, including PiktoChart (Available: https://piktochart.com), Infogr.am (Available: https://infogr.am), Venngage (Available: https://venngage.com), and Canva (Available: https://www.canva.com/create/infographics/).

Methods of Assessment and Analysis

To assess whether these added instructional elements benefited students and resulted in more well-designed, higher quality infographic assignments, we have collected approximately 60 Fall 2015 students' infographics and approximately 100 fall 2016 students' infographics. Each group's infographics were collected (with students' permission) and de-identified.

For this pilot analysis, we planned to evaluate and analyze a portion of this total data set: 42 student infographics, 21 each from the fall 2015 and fall 2016 semesters. Ultimately, our sample consisted of 20 from Fall 2015 and 21 from fall 2016. ${ }^{1}$ We collected this sample at random, choosing three group assignments from each section of the course. Roughly seven of the 16 sections from fall 2015 and 7 of the 12 sections from fall 2016 were represented in the sample. To facilitate a blind review, infographics were stripped of all information that would identify which section and which semester they were created in, and then assigned a number from one to 41. Using the rubric described above, two researchers first independently evaluated just 4 infographics, met to discuss any differences in their application of the rubric, and then negotiated

${ }^{1}$ This was because one of the assignments from the Fall 2015 sample did not actually include a full readable infographic. We discarded that group's work from this study. 
to a consensus (e.g. to scores for each category that were no more than 1 point apart).

Researchers then evaluated four more infographics, and again negotiated any differences. Again independently, each researcher then evaluated the remaining 32 infographics. Of these 32 scored infographics, 13 required further negotiation before their scores came within the accepted range of 1-point difference. Researchers' scores were then averaged and analyzed statistically for any significant differences.

\section{Results}

The table below shows average scores and standard deviation for each semester's sample of student infographics, both overall and by category.

\begin{tabular}{|l|c|c|}
\hline \multicolumn{1}{|c|}{ TOTAL SCORE } & $\begin{array}{c}\text { Fall 2015 Mean (Standard } \\
\text { Deviation) }\end{array}$ & Fall 2016 Mean (Standard Deviation) \\
\hline Audience (2pts) & $9.74(1.1570)$ & $9.90(1.2841)$ \\
\hline Communicates a message (1 pt) & $0.675(0.24467)$ & $0.75(0.20916)$ \\
\hline $\begin{array}{l}\text { Data Visualization - balance of } \\
\text { visual information with written } \\
\text { information }(1 \mathrm{pt})\end{array}$ & $0.8(0.25131)$ & $0.72619(0.24880)$ \\
\hline Fonts $(1 \mathrm{pt})$ & $0.9(0.14955)$ & $0.809524(0.23591)$ \\
\hline Size and Proportion $(1 \mathrm{pt})$ & $1(0)$ & $0.928571(0.16091)$ \\
\hline Title (1 pt) & $0.775(0.33344)$ & $0.75(0.27386)$ \\
\hline Effective use of color $(1 \mathrm{pt})$ & $0.8875(0.171583)$ & $0.8875(0.29880)$ \\
\hline Storytelling $(1 \mathrm{pt})$ & $0.7125(0.23332)$ & $0.583333(0.25413)$ \\
\hline Facts and figures $(1 \mathrm{pt})$ & $0.4875(0.39298)$ & $0.666667(0.31950)$ \\
\hline Citations $(1 \mathrm{pt})$ & $\mathbf{0 . 1 3 7 5}(0.319075)$ & $\mathbf{0 . 4 5 2 3 8 1}(0.4229290)$ \\
\hline File Format ${ }^{2}(2 \mathrm{pts})$ & $2(0)$ & $2(0)$ \\
\hline
\end{tabular}

Table 1: Breakdown and comparison of infographic scores by rubric category. Bold indicates statistically significant differences between semesters.

The visualized data appeared to be reasonably normally distributed. Initial statistical analyzing shows that the overall score result was not significantly different.

According to t-Test the data doesn't show a significant difference. The P Value for this pilot study is 0.667884 and for a significant difference the P Value should be less than 0.05 .

Since the researcher did not find a significant difference in the whole score, the analyzing of the component started. According to the fisher test the $\mathrm{P}$ value for nine components were not significant. The citation part shows a significant difference and the $\mathrm{P}$ value for that is 0.0485 . In

${ }^{2}$ For file format category all submissions received full scores because we asked them to submit a single PDF file that includes their name and assignment information. All of the students followed the direction. 
addition, three more component shows a little improvement that are audience; communicate a message and facts and figures. We were curious about students' engagements with the preparatory materials. Analyzing all quiz scores of fall 2016 shows that 58 students did not take the quiz and 199 students got the whole score.

\begin{tabular}{|l|l|}
\hline Mean & 10.5679612 \\
\hline Median & 13.5 \\
\hline $\begin{array}{l}\text { Standard } \\
\text { Deviation }\end{array}$ & 5.41957853 \\
\hline
\end{tabular}

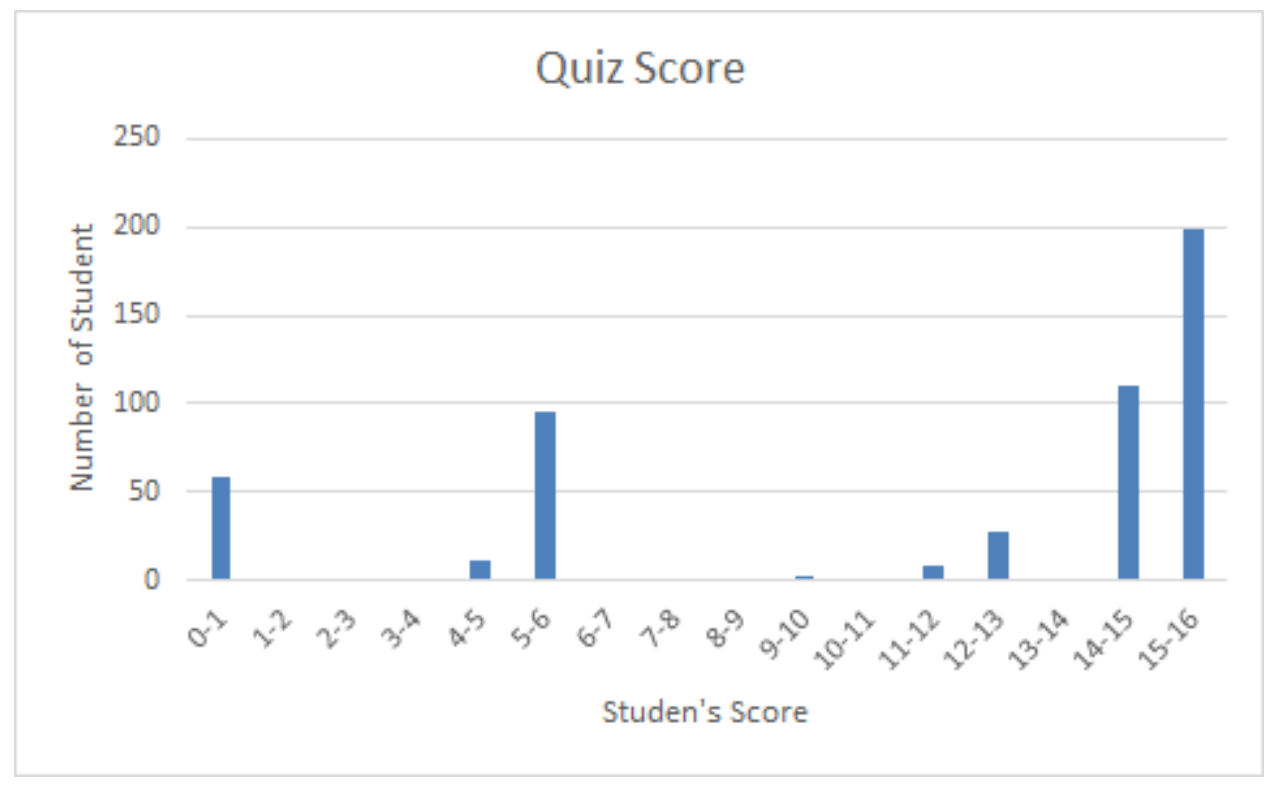

\section{Analysis \& Discussion}

Our goal has been to develop and improve the way our introductory design- thinking course teaches visualization, and to push students toward more sophisticated visualization skills. We hypothesized that when students learn to use the proposed rubric as a learning tool and evaluation measure, students' abilities to creatively conceptualize and produce relevant infographics, without copying existing templates, will improve significantly. From the pilot sample and analysis described above, we did not find that this was the case. According to these results, the pedagogical elements introduced in fall 2016 did not, overall, make a significant difference to students' performance. There are several potential explanations for why this was the case: issues with sampling across sections, the time constraints of a busy semester, inadequate feedback from graders, and/or students' autonomy. In a full semester, infographic is a small part of the overall project students are not involved in that for more than 2-3 sessions. Also, analyzing quiz results shows that about one third of the students didn't complete the quiz. 
Therefore, the research infographic samples also include those students that were not enough motivated to do the quiz. Furthermore, the graders didn't have enough time to give students consistent feedbacks about their individual infographic submissions. On the other hand, it is possible that part of the students did finalize their group infographic assignment without considering the feedbacks carefully.

Issues with Sampling

This study took place at the same time as a larger ongoing pedagogical initiative to integrated several sections of the Design Thinking course with sections of Introductory Composition and Speech Communication. For fall 2015, nearly all sections of Design Thinking were paired with Composition and Communication courses across campus, and therefore our samples from that semester are skewed toward those sections--only 3 of the 21 selected infographics from Fall 2015 were from student groups in non-integrated sections of the course. Most were from integrated sections where students received reinforcement on concepts of audience awareness, visual rhetoric, and presentation skills. Conversely, our sample from fall 2016 was somewhat more evenly distributed-- 13 of the 20 selected infographics from Fall 2016 were from nonintegrated sections, with 7 from integrated sections. The current research did not account for the potential effects of this program at any point in the study.

\section{Conclusion}

The goal of this project has been to develop and improve the way our introductory designthinking course teaches visualization, and to push students toward more sophisticated visualization skills. We hypothesize that when students learn to use the proposed rubric as a learning tool and evaluation measure, students' abilities to creatively conceptualize and produce relevant infographics, without copying existing templates, will improve significantly. We have planned to develop additional teaching materials for the spring 2017 sections of this course, including a new row to the rubric named "mechanics". Kaiser (2012). The mechanical part gives the credit for those infographic with no misspellings or grammatical errors. Instructors need more time to go over the principles of good infographics. Also, instructors need to teach and read infographic rubric in class and explain each part of it to students. Asking graders to provide feedback before each team developing its final infographic. Reminding students about quiz credit and asking them to do it before their infographic submission are also beneficial. For future study, we will also focus on more diverse population and use all Tech 120 classes and instructors.

First-year students in the College of Technology are in the beginning of their careers as designers, engineers, and innovators. They will be involved in research projects and presentations during their time in college. Strong visual communication skills will be useful skills in first semesters to use it in future works, not only in college but also beyond.

\section{References}

Allen, S., \& Knight, J. (2009). A method for collaboratively developing and validating a rubric. International Journal for the Scholarship of Teaching and Learning, 3(2), 10.

Bruff, D. (2012) A Crowdsourced Rubric for Evaluating Infographics. Agile Learning Blog. retrieved from http://derekbruff.org/?p=2081

Drago, W. A., \& Wagner, R. J. (2004). Vark preferred learning styles and online education. Management Research News, 27(7), 1-13. 
Dyjur, P., \& Li, L. (2015). Learning 21st century skills by engaging in an infographics assignment. Designing Responsive Pedagogy April 30-May 1, 2015 Calgary, Alberta, 62.

Kaiser, J. (2012) "Infographic rubric for student projects" Web 2.0 Education Blog. retrieved from https://web20edu.com/2012/05/17/infographic-rubric-for-student-projects/

Kibar, P. N., \& Akkoyunlu, B. (2014, October). A new approach to equip students with visual literacy skills: Use of infographics in education. In European Conference on Information Literacy (pp. 456-465). Springer International Publishing

Krauss, J. (2012). "Infographics: More than Words Can Say." Learning \& Leading with Technology, 39(5), 10-14. Retrieved from

Lankow, J., Ritchie, J., \& Crooks, R. (2012). Infographics: The power of visual storytelling. John Wiley \& Sons.

Learning Commons Library, University of Guelph. (2014). "Introduction to Infographics: Library Workshop." retrieved from https://uofginfographics.files.wordpress.com/2014/05/introtoinfographics_selfdirected_p owerpoint.pdf

McKee, R., \& Fryer, B. (2003). Storytelling that moves people. Harvard Business Review, 81(6), 51-55.

Mendenhall, S., \& Summers, S. (2015). Designing Research: Using Infographics to Teach Design Thinking. Composition. Journal of Global Literacies. Technologies and Emerging Pedagogies, 3(1), 359-371.

MLA citation: Schrock, Kathleen. Infographic rubric. Kathleen Schrock, 2012. Access date here. <http://kathyschrock.net/pdf/Schrock_infographic_rubric.pdf>.

Munzner, T. (2009). Visualization.

NAE. (2016). National Academy of Engineering Grand Challenges for Engineering. Retrieved from http://www.engineeringchallenges.org/challenges.aspx

Patel, N. (n.d.). "Title" Kissmetrics Blog: A Blog About Analytics, Marketing, and Testing. retrieved from: https://blog.kissmetrics.com/12-infographic-tips/

Ru, G., \& Ming, Z. Y. (2014, September). Infographics applied in design education. In Advanced Research and Technology in Industry Applications (WARTIA), 2014 IEEE Workshop on (pp. 984-986). IEEE

Schrock, Kathleen. (2014). "Addressing the CCSS with the Use of Infographics" Kathy Schrock's Kaffeeclatch Blog. retrieved from: http://blog.kathyschrock.net/2014/01/addressing-ccss-with-use-of-infographics.html

Schrock, Kathleen. (2012). Infographic Rubric http://www.schrockguide.net/uploads/3/9/2/2/392267/schrock_infographic_rubric.pdf

Seemiller, C. Assessing Student Engagement.

Smiciklas, M. (2012). The Power of Infographics: Using Pictures to Communicate and Connect with your Audiences. Indianapolis, IN: Que Publishing.

Stellmack, M. A., Konheim-Kalkstein, Y. L., Manor, J. E., Massey, A. R., \& Schmitz, J. A. P. (2009). An assessment of reliability and validity of a rubric for grading APA-style introductions. Teaching of Psychology, 36(2), 102-107.

Thaler, N., Kazemi, E., \& Huscher, C. (2009). Developing a rubric to assess student learning outcomes using a class assignment. Teaching of Psychology, 36(2), 113-116.

Toth, C. (2013). Revisiting a Genre Teaching Infographics in Business and Professional Communication Courses. Business Communication Quarterly, 76(4), 446-457. 
Tufte, E. R. (1997). Visual Explanations: Images and Quantitites, Evidence and Narrative. Cheshire, CT: Graphics Press.

Appendix A

Rubric 13/13 points

\begin{tabular}{|l|l|l|l|}
\hline COMPONENTS & \multicolumn{1}{|c|}{$\begin{array}{c}\text { MEETS } \\
\text { EXPECTATIONS }\end{array}$} & \multicolumn{1}{|c|}{$\begin{array}{c}\text { NEEDS MORE } \\
\text { WORK }\end{array}$} & UNSATISFACTORY \\
\hline Audience & $\begin{array}{l}\text { The audience is } \\
\text { identified and } \\
\text { described. The } \\
\text { infographic is } \\
\text { appropriate for your } \\
\text { target audience. (2 } \\
\text { points) }\end{array}$ & $\begin{array}{l}\text { The infographic is not } \\
\text { completely appropriate } \\
\text { for your target } \\
\text { audience or you didn't } \\
\text { identify the audience. } \\
\text { (1 point) }\end{array}$ & $\begin{array}{l}\text { The infographic is not } \\
\text { appropriate for your } \\
\text { target audience. }(0 \\
\text { points) }\end{array}$ \\
\hline $\begin{array}{l}\text { Communicates a } \\
\text { message }\end{array}$ & $\begin{array}{l}\text { The infographic is } \\
\text { simple and easy to }\end{array}$ & $\begin{array}{l}\text { The infographic } \\
\text { couldn't advance idea }\end{array}$ & $\begin{array}{l}\text { The infographic is not } \\
\text { easy to understand. }(0\end{array}$ \\
\hline
\end{tabular}




\begin{tabular}{|c|c|c|c|}
\hline & understand. (1 point) & $\begin{array}{l}\text { into a simple visual } \\
\text { form. } \\
\text { (1/2 point) }\end{array}$ & points) \\
\hline Storytelling & $\begin{array}{l}\text { Focus on the flow both } \\
\text { cognitively and } \\
\text { visually. ( } 1 \text { point) }\end{array}$ & $\begin{array}{l}\text { There is just cognitive } \\
\text { or visual flow. }(1 / 2 \\
\text { point })\end{array}$ & $\begin{array}{l}\text { There is no flow. ( } 0 \\
\text { points) }\end{array}$ \\
\hline Facts and figures & $\begin{array}{l}\text { The statistics are true } \\
\text { and sources are reliable. } \\
\text { (1 point) }\end{array}$ & $\begin{array}{l}\text { The statistics are not } \\
\text { true or the sources are } \\
\text { not reliable. }(1 / 2 \text { point })\end{array}$ & $\begin{array}{l}\text { The facts and figures } \\
\text { are not accurate. ( } 0 \\
\text { points) }\end{array}$ \\
\hline Title & $\begin{array}{l}\text { The title describes the } \\
\text { infographic and grabs } \\
\text { the user's attention. It is } \\
\text { short and easy to } \\
\text { understand quickly. (1 } \\
\text { point) }\end{array}$ & $\begin{array}{l}\text { The title of the } \\
\text { infographic may be a } \\
\text { bit too broad to allow } \\
\text { the viewer to } \\
\text { understand the main } \\
\text { points. } \\
\text { (1/2 point) }\end{array}$ & $\begin{array}{l}\text { There is no title. ( } 0 \\
\text { points) }\end{array}$ \\
\hline $\begin{array}{l}\text { Visual and } \\
\text { Textual } \\
\text { Composition }\end{array}$ & $\begin{array}{l}\text { Infographic has a good } \\
\text { balance of visual } \\
\text { information with written } \\
\text { information. (1 point) }\end{array}$ & $\begin{array}{l}\text { There is not a good } \\
\text { balance of visual } \\
\text { information with } \\
\text { written information. }(1 / 2 \\
\text { point) }\end{array}$ & $\begin{array}{l}\text { There is too much } \\
\text { written information. } \\
\text { ( } 0 \text { points })\end{array}$ \\
\hline $\begin{array}{l}\text { Effective use of } \\
\text { color }\end{array}$ & $\begin{array}{l}\text { There is a good balance } \\
\text { and contrast of color. (1 } \\
\text { point) }\end{array}$ & $\begin{array}{l}\text { Bright font colors on } \\
\text { bright background or } \\
\text { vice versa. (1/2 point) }\end{array}$ & $\begin{array}{l}\text { There is not a good } \\
\text { balance of color or } \\
\text { contrast. ( } 0 \text { points })\end{array}$ \\
\hline Fonts & $\begin{array}{l}\text { Make it easy to view } \\
\text { and read with using an } \\
\text { appropriate font. (1 } \\
\text { point) }\end{array}$ & $\begin{array}{l}\text { Some words in the } \\
\text { infographic are too } \\
\text { small to read. (1/2 point) }\end{array}$ & $\begin{array}{l}\text { The font(s) that used } \\
\text { in infographic make } \\
\text { the text almost } \\
\text { unreadable. ( } 0 \text { points) }\end{array}$ \\
\hline $\begin{array}{l}\text { Size and } \\
\text { Proportion }\end{array}$ & $\begin{array}{l}\text { Length and width } \\
\text { proportions are } \\
\text { appropriate. } \\
\text { Make it manageable } \\
\text { length and size. } \\
\text { (1 point) }\end{array}$ & $\begin{array}{l}\text { The infographic is not } \\
\text { in the right length. }(1 / 2 \\
\text { point) }\end{array}$ & $\begin{array}{l}\text { The infographic is too } \\
\text { big or too small. ( } \\
\text { points) }\end{array}$ \\
\hline Citations & $\begin{array}{l}\text { Full bibliographic } \\
\text { citations for all sources } \\
\text { used are included. (1 } \\
\text { point) }\end{array}$ & $\begin{array}{l}\text { The URLs of sources } \\
\text { used are included. (1/2 } \\
\text { point) }\end{array}$ & $\begin{array}{l}\text { No citations are } \\
\text { included. ( } 0 \text { points })\end{array}$ \\
\hline File Format & Great! Submitted as a & Has file as one single & Not in pdf format. ( 0 \\
\hline
\end{tabular}




\begin{tabular}{|l|l|l|l|} 
& $\begin{array}{l}\text { single pdf. Includes } \\
\text { your name, the course, } \\
\text { and assignment } \\
\text { information in the top. } \\
\text { (2 points) }\end{array}$ & $\begin{array}{l}\text { pdf or has included } \\
\text { proper documentation } \\
\text { on the top right, but } \\
\text { not both. (1 point) }\end{array}$ & points) \\
\hline
\end{tabular}

\section{Appendix B}

Fall 2015 Infographic Rubric

\begin{tabular}{|l|l|l|}
\hline Criteria & Meets Expectations & Needs Work \\
\hline Does it help tell the story? & $\begin{array}{l}\text { Draft infographic that visually } \\
\text { shows the solution, problem, and } \\
\text { rationale for how/why this } \\
\text { solution is innovative }\end{array}$ & Minimal or lacking. \\
\hline $\begin{array}{l}\text { Does it highlight useful } \\
\text { information? }\end{array}$ & $\begin{array}{l}\text { Draft image is clear and aligns } \\
\text { with Kickstarter document by } \\
\text { supporting the message }\end{array}$ & Minimal or lacking. \\
\hline Professionalism & $\begin{array}{l}\text { Professional and appropriate } \\
\text { message and visual. }\end{array}$ & Minimal or lacking. \\
\hline
\end{tabular}

Appendix C

Infographic Quiz

1- Which infographic is more relevant and has potential to excite the target audience?

2- Which infographic is simple and easy to understand?

3- Which infographic has a balance of visual information with written information?

4- Which infographic has fonts that are easy to view and read?

5- Which infographic has appropriate size and proportion?

6- Which infographic title describes the infographic and grabs the user's attention?

7- Which infographic has a good mix and contrast of color?

8- Which infographic tells a story using a smooth flow visually and conceptually?

9- Which infographic is more misleading?

10- Which infographic cites the sources?

Appendix D

Sample Student Work 


\section{Designing an Efficient Detour}

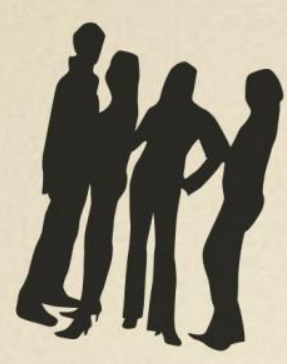

Talk to commuters to receive
their input

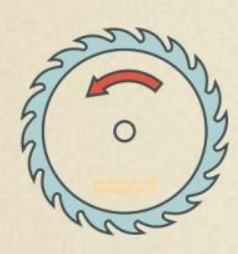

Map out and

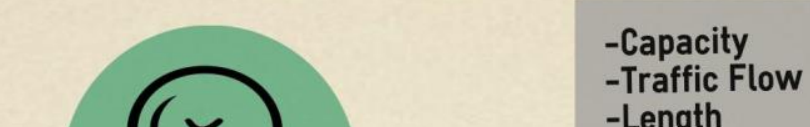

-Length

-Road Stability Build Detour Build Det
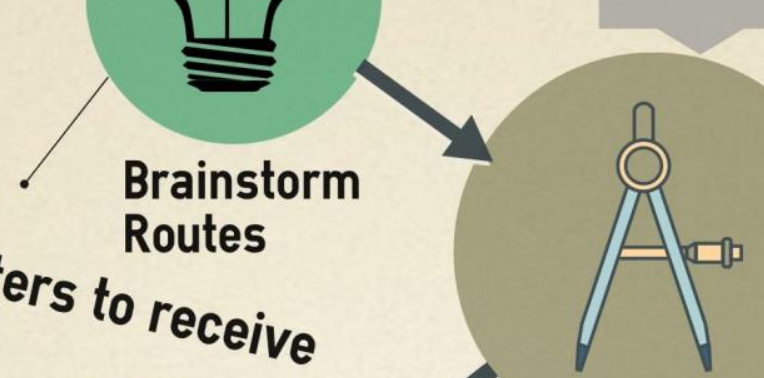

Test different routes

Essential that you take into consideration the commuters needs

\section{Enjoy your} stress-free detour!

Open the detour up to the public

Fall 2015 data for study 


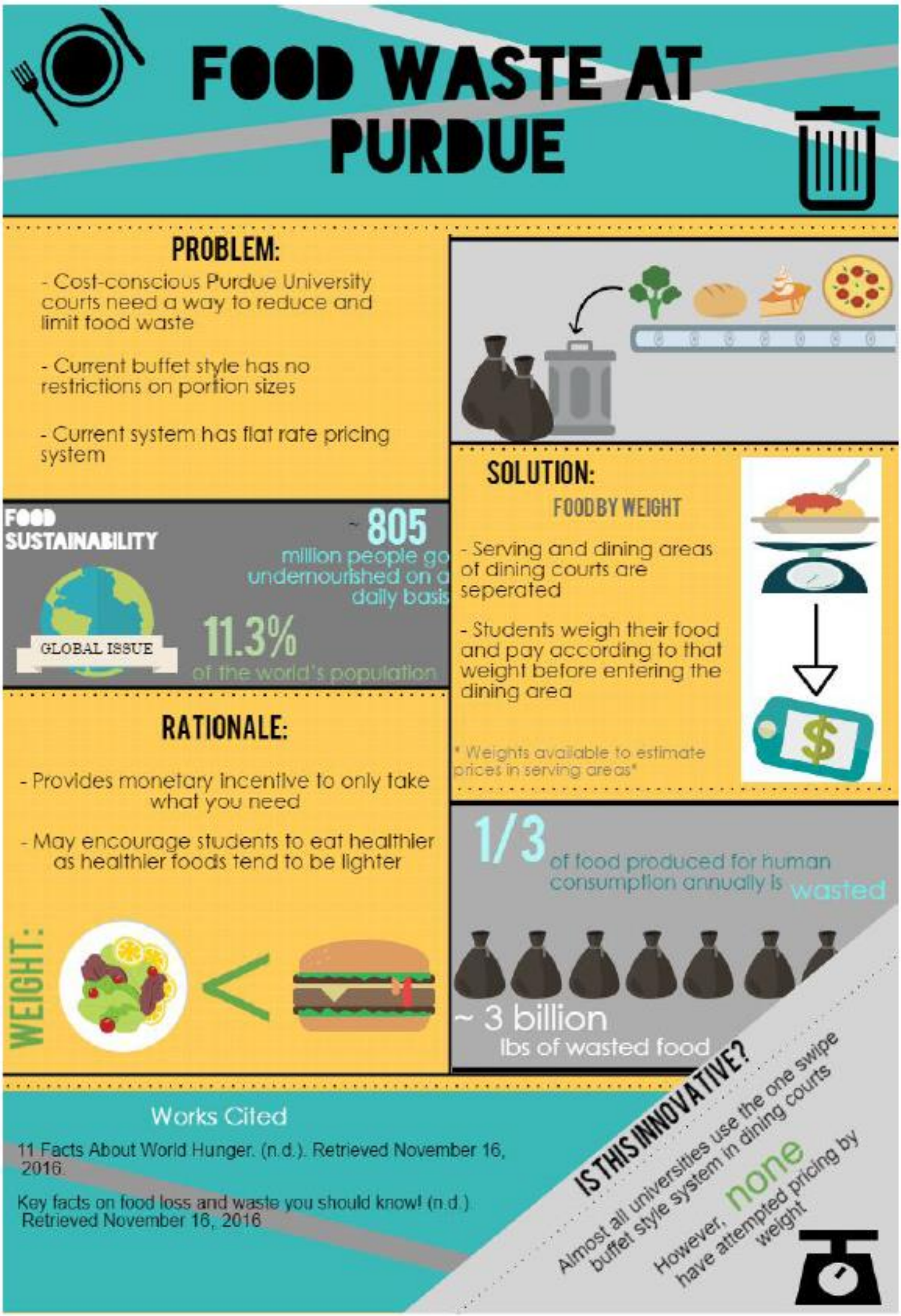


Fall 2016 data for study 